\title{
Academic librarian delegates chosen for WHCLIS
}

\author{
by Karin Begg
}

\author{
Member, ACRL Task Force on WHCLIS \\ Member, Massachusetts Planning \\ Committee for WHCLIS
}

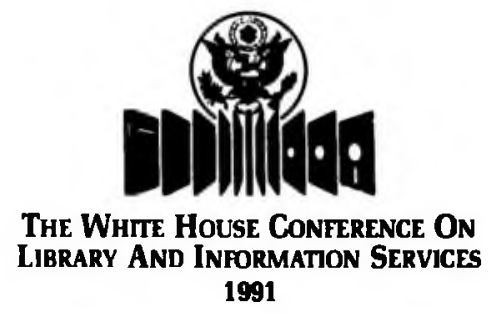

An important aspect of the upcoming White House Conference in Washington, D.C., continues to be the pre-conference activities taking place in the states and in the District of Columbia, American Samoa, Guam, the Commonwealth of the Northern Marianas, the Republic of the Marshall Islands, Puerto Rico, the US Virgin Islands, the Indian Nations (holding a pre-conference in Albuquerque, New Mexico), and by a coalition of federal libraries. Funding for these activities was included in the overall appropriation for WHCLIS, and has been apportioned based on size of state population. The states have been free to chose whatever activities they deem appropriate for the purpose.

Most states have planned state-wide Governors Conferences as a means of focusing on library issues at the state level. The agendas of these state conferences typically include an educational component in the form of speakers on library issues, especially as these relate to the WHCLIS themes of literacy, democracy and productivity. State agendas for the federal conference will often be established at the state conferences, and state delegates to attend WHCLIS in Washington will commonly be elected/selected in conjunction with these events. The state conferences are usually limited to specifically chosen representatives, and it is most usually from these representatives that the WHCLIS delegates from that state are designated. Some states will have a formal orientation/training program for its delegates.

Many states are also sponsoring regional activities, usually prior to the state-wide meetings, in such forms as mini-conferences and grass-roots "speak-outs". Local newspapers and television outlets are being used broadly to distribute information about WHCLIS-related local library issues and about the various local conference activities. A few states will make use of teleconferencing as a way of reaching a broader audience. Typically, it is the state librarian who is the focus of a state's WHCLIS activities and arrangements, but some variation on this is also the case from state to state.
Massachusetts is unique in having concentrated its pre-conference efforts on the delegate selection and preparation process, with the aim of producing a core of library advocates committed to following through on the Massachusetts library agenda postWHCLIS. The Massachusetts WHCLIS Planning Committee interviewed delegate candidates identified through a state-wide nomination and application process (there were over eighty applications for the five library and information professional slots on the delegation, including one alternate).

The Massachusetts WHCLIS delegates have had three day-long briefing sessions as of the end of January 1991 and in February they will have a fourth, this one on library funding and on research library issues. They will attend the joint Northeastern state delegate convention in April to put a regional spin on their agenda and to learn skills specific to being an effective delegate. The Massachusetts WHCLIS schedule is tentatively expected to include a post-conference.

Much of the activity in the states bears out Stuart Forth's observation in this column two months ago, which is the "heavy emphasis on public libraries" which is the hallmark of the second WHCLIS just as it was for the first. Academic librarians will need to be particularly vigilant to ensure the inclusion of issues of strategic concern to academic and research libraries in the WHCLIS agenda.

Local chapters of ACRL can be one agent for maintaining the focus on academic library agenda items. For instance, the ACRL New England Chapter Board has adopted a regional academic agenda which draws in part on the ACRL position paper and which also addresses copyright issues and federal government suppression of information, the desired re-authorization of LSCA in 1994 "to support and promote interlibrary cooperation", the promotion of international outreach, the emergence of the electronic scholarly joumal, and the spiraling costs of journal subscriptions in traditional formats. This agenda has been disseminated throughout New England through the chapter newsletter, in addition to which academic dele- 
gates to WHCLIS from three states serve on the New England Chapter Board and will carry this agenda to their state delegations.

Because of the specifics of the WHCLIS law, the number of academic librarian delegates to WHCLIS is bound to be small relative to the size of the overall number of delegates. The law decrees both the size of each state delegation (the same number as the state's congressional delegation) and the proportion of interests to be represented on each delegation (library professionals can only be a quarter of the delegates). It stands to reason that states may want to balance their librarian representation among the many library types; and this supposition is being borne out by reality.

By the end of January 1991, only about half the states had completed their delegate-selection activities, and only about a quarter of the delegations had been certified with the Washington WHCLIS office. Academic librarian delegates known so far:

Colorado: Camila Alire (University of Colorado/ Denver)

Connecticut: David Lewis (University of Connecticut)

Florida: Lydia Acosta (University of Tampa)

Georgia: Charles Beard (West Georgia College) Ralph Russell (Georgia State University)

Guam: Mark C. Goniwiecha (University of Guam)

Indiana: Jim Neal (Indiana University)

Louisiana: Orella Brazile (Southern Louisiana University, Shreveport/Bossier City Campus)

Maine: Elaine Albright (University of Maine/ Orono)

Rhode Island: Marlene Lopes (Rhode Island College)

Massachusetts: Bessie Hahn (Brandeis University) Mark Scott (MIT)

Virginia: Lynn Cochrane (Virginia Polytechnic) Nancy Marshall (College of William \& Mary)

If you are or know of an academic or research librarian WHCLIS delegate who is not identified on this list, please notify Patricia A. Wand, Chair of the ACRL Task Force on WHCLIS, at American University Library, Washington, D.C., 20016, telephone number (202) 885-3237.

At its meetings at Midwinter, the ACRL Task Force on WHCLIS recommended that all academic librarians who are WHCLIS delegates or alternates get together in conjunction with the ACRL President's program on Monday afternoon, July 1, at the ALA Annual Conference in Atlanta this summer in order to discuss the shared academic agenda for WHCLIS. The ACRL President, Barbara Ford, has endorsed this suggestion and has asked her conference planning committee to accommodate it.
State pre-WHCLIS activities scheduled for 1991 include the following.

Alabama: Governor's Conference March 5-6, at which WHCLIS delegates will be elected.

Alaska: State conference March 1, in conjunction with the Alaska Library Association Conference.

Arizona: State conference January 24-25, attended by local delegates selected earlier at fifteen county teleconference sites.

Arkansas: State conference in March; sub-regional post-conferences in the fall of 1991.

Delaware: State conference March 8-9.

Iowa: State conference April 30-May 2 on the theme of "Iowa Libraries: Your Access for Information!"

Kentucky: Governor's Conference February 19 to serve as an "issues forum" led by the previously elected WHCLIS delegates.

Louisiana: Presentation to the 1991 Louisiana Legislature of the state WHCLIS agenda which was developed through seven regional meetings in 1990.

Mississippi: State conference January 11-12 at which WHCLIS delegates will be elected and the state agenda will be voted on.

Montana: Govemor's Conference January 6-8 reflecting the vision "that every citizen be information rich."

Nebraska: State conference February 23-26 on the theme of "Nebraska Information Partnerships." The state WHCLIS agenda was determined in part through an information needs survey of 4,000 citizens.

New Hampshire: State conference in February.

North Carolina: Governor's Conference in February.

Texas: State conference January 4, on the theme of "Texas Libraries: Building Community Partnerships."

Utah: Governor's Conference February 28March 2.

Washington: State conference February 28-March 2.

Wisconsin: State conference February 7-8, to review state WHCLIS resolutions which have come out of five regional one-day meetings.

District of Columbia: Pre-conference in March.

US Virgin Islands: Territorial conference in March.

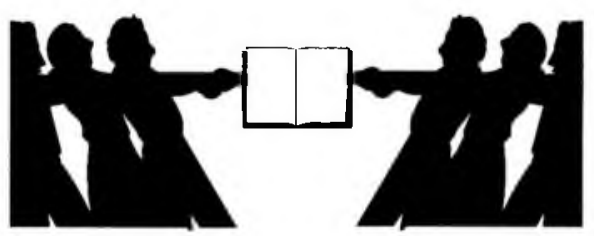

